\title{
Studi Tentang Tugas Tanggung Jawab Gereja Serta Implikasinya Terhadap Pelayanan Misi dan Penginjilan di Kota Batam
}

\author{
Selvyen Sophia* ${ }^{1}$,Fransiskus Irwan Widjaja, ${ }^{2}$ Alexander Djuang Papay ${ }^{3}$ \\ Prodi Teologi, STT Real Batam \\ Prodi Teologi, STT Real Batam \\ Prodi Teologi, STT Real Batam \\ Selvinchute99@gmail.com
}

\begin{abstract}
Sin is a violation of God's provisions since the first human was made which ultimately results in eternal death or eternal damnation for all people. So that everyone does not experience eternal death, it is necessary for a church that understands the task of its responsibilities in carrying out missionary and missionary services. The original tribe of Batam city is the Malay tribe who need news about Jesus the redeemer of the price of eternal death, because they are one of the tribes that has not been reached by the preaching of the gospel. So in this study, researchers formulated the problem as follows: What are the forms of mission and evangelistic services in every church in Batam City ?; How do churches in Batam City carry out their duties and responsibilities in missionary and evangelistic ministry ?; What are the duties and calls of the church? Researchers conducted research using a descriptive survey approach through a qualitative approach to identify and explain the duties of the existing church responsibility in the city of Batam for missionary services and evangelism to Malay tribes who are indigenous to the City of Batam. From the data collected by researchers, the results show that the church in Batam City has not yet fully carried out its responsibility in mission and evangelism, which is to empower the congregation in missionary and evangelistic services, both through teaching with the concept of missionary discipleship, training for proficient in carrying out missionary and evangelistic services, facilitate the congregation in missionary and evangelistic services especially to Malay tribes in Batam City because the biggest obstacle experienced by the church is the self-focused congregation so that it forgets the main work which is the great commission and ultimately evangelism is only carried out by local shepherds who should be the task of all church components.
\end{abstract}

Keywords: Integrity; Christian leadership; Millennial Leadership.

\begin{abstract}
Abstrak
Dosa adalah pelanggaran ketentuan Allah sejak manusia pertama dijadikan yang pada akhirnya mengakibatkan kematian kekal atau hukuman kebinasaan selama-lamanya bagi semua orang. Agar setiap orang tidak mengalami kematian kekal, diperlukan gereja yang memahami akan tugas tanggungjawabnya dalam pelaksanaan pelayanan misi dan penginjilan. Suku asli kota Batam adalah suku melayu yang membutuhkan berita tentang Yesus sang penebus harga kematian kekal, sebab mereka merupakan salah satu suku yang belum terjangkau oleh pemberitaan Injil. Maka dalam penelitian ini, peneliti merumuskan permasalahan sebagai berikut: Bagaimana bentuk pelayanan misi dan penginjilan yang ada di setiap Gereja di Kota Batam?; Bagaimana gereja di Kota Batam mengerjakan tugas dan tanggungjawabnya dalam pelayanan misi dan penginjilan?; Apa saja tugas dan panggilan gereja? Peneliti melakukan penelitian dengan menggunakan pendekatan survey deskriptif melalui pendekatan kualitatif untuk mengidentifikasi dan menjelaskan tugas tanggungjawab gereja yang ada dikota Batam terhadap pelayanan misi dan penginjilan kepada suku melayu yang adalah suku asli Kota Batam. Dari Data yang telah dikumpulkan peneliti
\end{abstract}


mendapatkan hasil bahwasannya gereja di Kota Batam belum sepenuhnya mengerjakan tugas tanggungjawabnya dalam pelayanan misi dan penginjilan yang adalah memberdayakan jemaatnya dalam pelayanan misi dan penginjilan, baik lewat pengajaran dengan konsep pemuridan missioner, pelatihan untuk cakap melakukan pelayanan misi dan penginjilan, memfasilitasi jemaat dalam pelayanan misi dan penginjilan terkhusus kepada suku melayu di Kota Batam karena kendala terbesar yang dialami gereja adalah jemaat yang berfokus kepada diri sendiri sehingga melupakan pekerjaan utama yang adalah amanat agung dan pada akhirnya penginjilan hanya dilakukan oleh gembala setempat yang seharusnya itu merupakan tugas dari semua komponan gereja.Kata kunci: Integritas; Kepemimpinan Kristen; Kepemimpinan Milenial.

\section{PENDAHULUAN}

Hadirnya gereja di dalam dunia karena adanya tugas yang harus disampaikan kepada dunia. Salah satu tugas gereja adalah untuk memberitakan kabar sukacita kepada dunia tentang karya penyelamatan Allah kepada manusia yang tertuang dalam Amanat Agung (Matius 28:19-20). Amanat Agung ini bukan merupakan sebuah tantangan melainkan suatu tanggungjawab yang harus dipikul, dan diperuntukkan bagi semua orang percaya untuk pergi ke seluruh dunia dalam memberitakan Injil kepada segala makhluk. ${ }^{1}$ Setiap orang percaya mengemban amanat untuk membaktikan diri dalam membuat Injil menjadi perhatian seluruh umat manusia, ini merupakan tanggung jawab yang tidak dapat diabaikan. ${ }^{2}$ Untuk itulah, gereja ada didunia harus membawa perubahan.

Pelayanan misi dan Penginjilan merupakan istilah yang didiskusikan secara luas. Banyak buku telah ditulis tentang misi dan penginjilan. Mimbar-mimbar gereja banyak menyuarakan tentang misi dan penginjilan. Dan orang-orang Kristen dimobilisasi untuk terlibat misi dan penginjilan. Namun, Permasalahan terbesar yang datang dalam Gereja sendiri, dimana gereja-gereja sekarang ini banyak yang tidak memiliki jiwa misi dan penginjilan. Atau gereja hanya ada, tidak memahami tugas tanggung jawabnya. Tradisi gereja begitu mengikat kehidupan berjemaat sehingga pertambahan jumlah karena kelahiran dan perpindahan anggota gereja satu ke gereja yang lain bukan karena hasil misi ke luar. Terutama hal ini terjadi dengan gereja yang merasa puas karena jumlah jemaat (kuantitasnya) saja. Hal ini dapat dibuktikan dengan data yang di keluarkan oleh Bilangan Research Centre (BRC) yang melakukan studi komparatif lintas gereja di Indonesia, terhadap 4.934 Pendeta Di 34 Kabupaten/Kota yang dilakukan oleh Lembaga Pengkajian Bilangan Research Center tahun 2018, terkait perkembangan gereja terkini menjelaskan bahwa ternyata pertumbuhan gereja di Indonesia tidak terlalu pesat jauh dari apa yang disebut sebagai ledakan pertumbuhan. ${ }^{3}$ Kebanyakan pertumbuhan gereja di Indonesia lebih merupakan pindahan atau migrasi dari jemaat gereja lain (42.3\%), atau, pertumbuhan

\footnotetext{
${ }^{1}$ Murray W. Downey, Cara-Cara Memenangkan Jiwa (Bandung: Yayasan Kalam Hidup, 1957).

${ }^{2}$ J. I. Packer, Penginjilan Dan Kedaulatan Allah Evangelism And The Sovereignty of God (Surabaya: Momentum, 2003).

${ }^{3}$ Sabar Manahan Hutagalung, Fransiskus Irwan Widjaja, Daniel Ginting, Mengutip Centre for the Study of Global Christianity, Christianity in Global Context, 1970.
} 
biologis (28.1\%). Sedangkan pertumbuhan jemaat dari hasil "penginjilan" hanya $2.1 \%$, artinya sebetulnya tidak ada pertumbuhan. ${ }^{4}$

Terkhusus Gereja di Kota Batam dengan Pulau yang luasnya $715 \mathrm{~km}^{2}$ ini memiliki populasi tahun di tahun 2019 sebanyak 1.433 jiwa ${ }^{5}$ dengan jumlah gereja sekitar 437 gereja dengan 74 denominasi ${ }^{6}$ menempatkan kota ini sebagai Provinsi pertumbuhan Kristen yang tertinggi di Indonesia. ${ }^{7}$ Namun Gereja di Kota Batam yang mengadopsi suku melayu tidaklah terlihat. Hal ini dapat dibuktikan dari data beberapa gereja yang telah di teliti oleh peneliti sebagai berikut: ${ }^{8}$

\begin{tabular}{|c|c|c|c|c|c|}
\hline No & $\begin{array}{l}\text { Nama } \\
\text { Denominasi } \\
\text { Gereja }\end{array}$ & $\begin{array}{l}\text { Tahun } \\
\text { Berdiri }\end{array}$ & $\begin{array}{l}\text { Jumlah } \\
\text { Jemaat/KK }\end{array}$ & Pengurus Gereja & $\begin{array}{l}\text { Suku Asli } \\
\text { Kota } \\
\text { Batam }\end{array}$ \\
\hline 1 & $\begin{array}{l}\text { GKKI Air Hidup } \\
\text { Cabang Tiban }\end{array}$ & 2014 & 20 & Pdt.Daranto Berutu & Tidak Ada \\
\hline 2 & GKII Tiban & 1988 & 250 & $\begin{array}{l}\text { Pdt. Pinantun Hot } \\
\text { Asi Hutabarat, S.Th }\end{array}$ & Tidak Ada \\
\hline 3 & $\begin{array}{ll}\text { GPDI } & \text { Filadelfia } \\
\text { Tiban } & \\
\end{array}$ & 2000 & 65 & Pdt. Fati Elizai & Tidak ada \\
\hline 4 & GKPS Lubuk Baja & 1986 & 50 & $\begin{array}{l}\text { Pdt. Dorce Dorkau } \\
\text { Debora }\end{array}$ & Tidak Ada \\
\hline 5 & HKBP Agave & 2004 & 250 & $\begin{array}{l}\text { Pdt. Albenar Silaen, } \\
\text { S.Th }\end{array}$ & Tidak Ada \\
\hline 6 & GBI Center Point & 2004 & 300 & Pdt. Ir Tjin Fen & Tidak Ada \\
\hline 7 & $\begin{array}{l}\text { GBI Tabgha Cab. } \\
\text { Bengkong }\end{array}$ & 2003 & 1500 & $\begin{array}{l}\text { Pdt. Filemon } \\
\text { Meliata, M.P.M }\end{array}$ & 2 Orang \\
\hline 8 & $\begin{array}{l}\begin{array}{l}\text { GBI Kampung Air } \\
\text { (Batam Kota) }\end{array} \\
\end{array}$ & 2009 & 40 & $\begin{array}{ll}\text { Pdt. } & \text { Rahmadi } \\
\text { Ginting } & \\
\end{array}$ & 4 Orang \\
\hline 9 & GPT Lubuk Baja & 1995 & 13 & $\begin{array}{ll}\text { Pdt. } & \text { Edison } \\
\text { Sihombing } & \\
\end{array}$ & Tidak Ada \\
\hline 10 & GBIS Batu Ampar & 2000 & 180 & Pdt. Yaaro Zebua & 2 Orang \\
\hline 11 & $\begin{array}{ll}\text { GBI } & \text { Bengkong } \\
\text { Tengah }\end{array}$ & 1992 & 75 & $\begin{array}{l}\text { Pdt. Makmur Butar- } \\
\text { Butar }\end{array}$ & Tidak Ada \\
\hline 12 & $\begin{array}{l}\text { GBI Bengkong } \\
\text { Mahkota }\end{array}$ & 2003 & 15 & $\begin{array}{ll}\text { Pdt. } & \text { Ferry } \\
\text { Pandiangan } & \\
\end{array}$ & Tidak Ada \\
\hline 13 & $\begin{array}{l}\begin{array}{l}\text { Gereja } \\
\text { Diaspora }\end{array} \\
\end{array}$ & 2012 & 54 & $\begin{array}{l}\text { Pdt. Pieter Up Tol } \\
\text { Seja }\end{array}$ & Tidak Ada \\
\hline 14 & $\begin{array}{l}\text { GBI Waterpoint } \\
\text { city Sekupang }\end{array}$ & 2007 & 13 & $\begin{array}{ll}\text { Pdt. } & \text { Sandra } \\
\text { Lodwyok }\end{array}$ & Tidak Ada \\
\hline
\end{tabular}

\footnotetext{
${ }^{4}$ Ibid.

5 "Badan Pusat Statistik Kota Batam," n.d.

${ }^{6}$ Fransiskus Irwan Widjaja, Tentang Data Gereja, 2015.

${ }^{7}$ Fransiskus Irwan Widjaja, Misiologi Antara Teori, Fakta Dan Pengalaman, 1st ed. (Batam: Andi Offset Yogyakarta, 2018).

${ }^{8}$ Hasil Penelitian Kelompok Mahasiswa S2 Dalam Mata Kuliah Church Planting Dan Strategi Misi Pada Tgl 31 Oktober, 2019.
} 


\begin{tabular}{|c|c|c|c|c|c|}
\hline 15 & $\begin{array}{ll}\text { GBI } & \text { Tiban } \\
\text { Mentarau } & \end{array}$ & 2008 & 25 & $\begin{array}{ll}\text { Pdt. } & \text { Abdon } \\
\text { Situmorang } & \end{array}$ & Tidak Ada \\
\hline 16 & GISI Batam Kota & 1993 & 50 & $\begin{array}{ll}\text { Pdt. } & \text { Bungsu } \\
\text { Darmawan } & \end{array}$ & 3 Orang \\
\hline 17 & GPPS & 1986 & 50 & $\begin{array}{l}\text { Pdt. Hany S. } \\
\text { Gumolili }\end{array}$ & Tidak Ada \\
\hline 18 & $\begin{array}{ll}\text { GBKP } & \text { Batam } \\
\text { Center } & \\
\end{array}$ & 1991 & \pm 300 & $\begin{array}{l}\text { Pdt. Laharena Br. } \\
\text { Sinuhadji }\end{array}$ & Tidak Ada \\
\hline 19 & $\begin{array}{l}\text { GPDI Bethesda } \\
\text { Batam Kota }\end{array}$ & 1999 & 1000 & Pdt. Allan Parangan & Tidak Ada \\
\hline 20 & $\begin{array}{l}\text { GJKI Metanoia } \\
\text { Batam }\end{array}$ & 2013 & 70 & $\begin{array}{l}\text { Pdt. Tulus M } \\
\text { Sihombing }\end{array}$ & Tidak Ada \\
\hline 21 & GBI Jehovah Jireh & 2014 & 75 & Pdt. Ferdinandes & Tidak Ada \\
\hline 22 & $\begin{array}{l}\text { GTDI } \\
\text { Batam }\end{array}$ & 2016 & 150 & Pdt. Saharman Gea & 1 Orang \\
\hline 23 & GMII Eben Haezer & 2003 & 40 & Pdt. Hardiantus & 1 Orang \\
\hline
\end{tabular}

\section{METODE}

Penelitian ini menggunakan pendekatan survey deskriptif melalui pendekatan kualitatif untuk mengidentifikasi dan menjelaskan gereja yang ada .

1. Pengumpulan data secara kualitatif di lapangan dalam bentuk wawancara langsung, interview gereja-gereja yang ada di Kota Bata

2. Penggalian literature mengenai pelayanan misi, penginjilan, dan tugas tanggungjawab gereja baik melalui penelitian literature, buku buku, jurnal-jurnal baik di dalam negeri maupun luar negri.

\section{HASIL DAN PEMBAHASAN}

Istilah Istilah misi (berasal dari bahasa latin mission yang diangkat dari kata dasar mittere yang artinya to send, mengirim, mengutus, act of sending. Padanan dari kata Yunani ialah apostello. ${ }^{9}$ Misi adalah ilmu tentang mengutus dan mengirim orang untuk menyampaikan Kabar Baik kepada bangsa-bangsa. Dalam konteks ini mengirim atau mengutus orang untuk memberitakan kabar sukacita kepada orang-orang yang belum mengenal siapa Yesus. Misi berbicara tentang Allah sebagai pengutus, dimana Ia adalah sumber, Inisiator, dinamisator, pelaksana dan penggenap misiNya yang aktif dan umat Allah adalah respon tanggung jawab yang berada dalam lingkup keaktifan Allah. Secara rinci, misi berbicara mengenai tugas (mission) yang dimandatkan Allah kepada umatNya untuk menjadi alat shalom-Nya kepada manusia dari segala bangsa. Jadi, penekanan misi disini terletak pada konsep bahwa Allah adalah sumber, inisiator, dinamisator, pelaksana dan penggenap dari misiNya. ${ }^{10}$ Dengan kata lain, misi diartikan sebagai pengiriman orang percaya dimana Allah bertindak sebagai pengutus untuk menyampaikan kabar baik yang

\footnotetext{
${ }^{9}$ Arie De Kuiper, Missiologia: Ilmu Pekabaran Injil (Jakarta: BPK Gunung Mulia, 2006).

${ }^{10}$ Yakob Tomatala, Teologi Misi (Jakarta: YT Leadership Foundation, 2003).
} 
adalah Yesus Kristus keapda bangsa-bangsa yan belum mengenal Dia. Jika dihubungkan dengan pelayanan misi, itu merupakan seluruh dimensi tugas Kristen (Ef. 4:8,12). Jadi, pelayanan misi berarti keberadaan orang percaya dimuka bumi sebagai alat pelaksana dari misi Allah Tritunggal. Semua murid Kristus terpanggil kepada tugas pelayanan ini, memberitakan kabar keselamatan dari Allah kepada manusia agar mereka menjadi percaya dan diselamatkan.

Misi dan penginjilan saling berhubungan erat dimana missiologi telah dianggap induk dari semua ilmu misi termasuk penginjilan. Dengan demikian, didalam misi ada penginjilan dan di dalam penginjilan dapat ditemukan misi (pengutusan). ${ }^{11}$ Penginjilan memiliki arti kegiatan atau tugas yang berhubungan dengan pewartaan/ penyebaran isi "kabar baik" dari Allan bahwa Yesus Kristus adalah Juruselamat dunia yang datang ke dunia untuk menggenapkan Janji Allah guna membebaskan umatNya dari dosa mereka. Hal ini sependapat dengan D.W. Ellis yang menjelaskan bahwa penginjilan merupakan upaya pewartaan: Yesus Kristus sebagai Juruselamat, sehingga setiap orang yang diinjili akan menerimaNya, taat dan melayaniNya, serta hidup dalam persekutuan gerejaNya. ${ }^{12} \mathrm{Hal}$ yang senada juga dinyatakan oleh J.I. Packer bahwa penginjilan adalah pengkomunikasian yang dilakukan orang Kristen sebagai penyambung lidah Allah untuk menyampaikan berita pengampunan Allah kepada manusia berdosa. ${ }^{13}$

Kata gereja diterjemahkan dari kata Yunani Ekklesia; berasal dari kata ek (keluar) dan kalleo (memanggil). Kata Ekklesia biasanya digunakan untuk menggambarkan sekumpulan orang, baik perkumpulan/ perhimpunan secara resmi maupun tidak resmi, yang kadang-kadang hanya berkerumunan Bersama sebagai massa (Kis. 19:32, 39, 41). Dan perhimpunan tersebut biasanya dalam pengertian politik dan bukan dalam pengertian keagamaan. Ditambahkan, kata tersebut tidak menjelaskan mengenai orangnya, tetapi mengenai pertemuannya. ${ }^{14}$

Dalam Bahasa Inggris Istilah gereja, dalam bahasa Inggris Church, dan disebut dengan kata Kirk (Belanda) serta Kirche dalam bahasa Jerman tidak berasal dari kata ekklesia tetapi dari kata Gerika kuriakon yang artinya adalah milik Tuhan. Kata ini menekankan bahwa Gereja adalah milik Tuhan. ${ }^{15}$ Kata tersebut hanya digunakan dua kali dalam Perjanjian Baru; pertama dipakai untuk Perjamuan Kudus (1 Kor 11:20) dan kedua untuk hari Tuhan (Why 1:10). Dengan demikian istilah gereja yaitu sekelompok orang yang telah dipanggil keluar dari dunia dan menjadi milik Allah. ${ }^{16}$

${ }^{11}$ Harianto GP, Pengantar Misiologi, Misiologi Sebagai Jalan Menuju Pertumbuhan (Yogyakarta: Andi Offset, 2012), 7.

${ }^{12}$ D. W. Ellis, Metode Penginjilan: Istimewa Tepat Guna Bagi Penginjil Awam Praktis Dan Taktis (Jakarta: Yayasan Komunikasi Bina Kasih OMF, 1999).

${ }^{13}$ Packer, Penginjilan Dan Kedaulatan Allah Evangelism And The Sovereignty of God.

${ }^{14}$ Charles C. Ryrie, Teologi Dasar, Buku 2. (Yogyakarta: Andi Offset, 2000).

${ }_{15}^{15}$ Louis Berkhof, Teologi Sistematika, Volume 5 (Surabaya: Lembaga Reformed Injili Indonesia, 1997).

${ }^{16}$ Henry Clarence Thiessen, Teologi Sistematika (Malang: Gandum Mas, 2003). 
Dalam Perjanjian Baru, berdasarkan konkordansi bahasa Yunani ada 114 pemakaian ekklesia dalam PB. Lima diantaranya bermakna umum (Kis. 19:32, 39, 40; Yak 2:2; Kis. 7:38), sisanya 109 berkaitan dengan gereja (mis. Ef. 1:22,23; Rm 16:5; 1 Kor. 16:19; Kol. 4:15; Fil.2

\section{Keadaan Pelayanan Misi dan Penginjilan ke Suku Melayu di Kota Batam}

Gereja di Kota Batam, lebih banyak berada pada daerah-daerah perkotaan. Data ini dapat dilihat jelas pada gambar dibawah ini: ${ }^{17}$

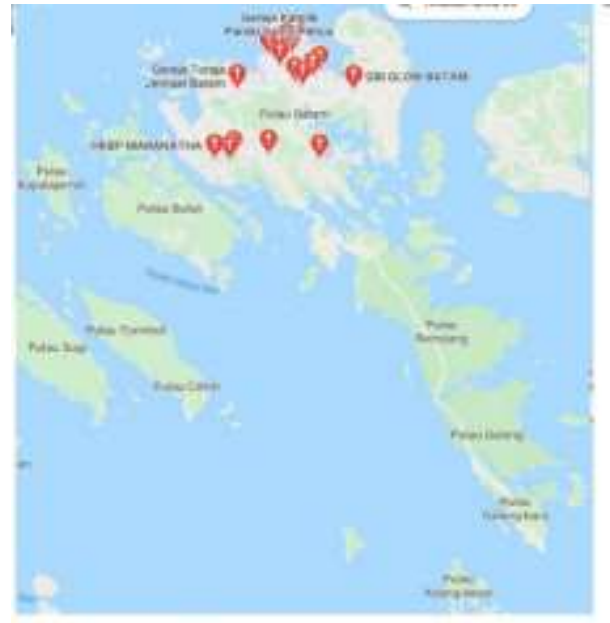

Tabel Lokasi Gereja-gereja yang ada di Kota Batam

Dari gambar diatas menyatakan bahwasannya gereja lebih banyak berada di daerah-daerah perkotaan sehingga tidak berfokus kepada penginjilan suku melayu yang berada di daerah sekitar perairan karena di daerah perkotaan lebih cenderung masyarkat heterogen. Sebagaimana hasil wawancara dengan salah satu pendeta di kota Batam yang menyatakan bahwa di lingkungan gereja mereka tidak ada suku melayu sehingga mereka lebih cenderung tidak penginjilan kepada suku tersebut. ${ }^{18}$

Dalam ruang lingkup penginjilan, Gereja di kota Batam lebih banyak kepada bentuk penginjilan pribadi. Sebagaimana data dibawah ini: ${ }^{19}$

Tabel Penginjilan oleh Gereja

\begin{tabular}{|c|c|c|c|l|l|}
\hline No & Nama Denominasi Gereja & $\begin{array}{l}\text { Tahun } \\
\text { Berdiri }\end{array}$ & $\begin{array}{c}\text { Jumlah } \\
\text { Jemaat/ } \\
\text { KK }\end{array}$ & Pengurus Gereja & Penginjilan \\
\hline 1 & $\begin{array}{l}\text { GKKI Air Hidup Cabang } \\
\text { Tiban }\end{array}$ & 2014 & 20 & Pdt. Daranto Berutu & Tidak Ada \\
\hline
\end{tabular}

17“Https://Www.Google.Com/Maps/Search/Gereja+yang+ada+di+kota+batam/@0.8685112,104.0001183,10.5 z?Hl=id," 12 Juni 2020.

${ }^{18}$ Hasil Wawancara Dengan Pdt. Tulus Sihombing Pada Tgl 31 Oktober, 2019.

${ }^{19}$ Hasil Penelitian Kelompok Mahasiswa S2 Dalam Mata Kuliah Church Planting Dan Strategi Misi Pada Tgl 31 Oktober. 


\begin{tabular}{|c|c|c|c|c|c|}
\hline 2 & GKII Tiban & 1988 & 250 & $\begin{array}{l}\text { Pdt. Pinantun Hot } \\
\text { Asi Hutabarat, S.Th }\end{array}$ & $\begin{array}{l}\text { Ada (KKR, } \\
\text { bagikan Traktat) }\end{array}$ \\
\hline 3 & GPDI Filadelfia Tiban & 2000 & 65 & Pdt. Fati Elizai & Tidak Ada \\
\hline 4 & GKPS Lubuk Baja & 1986 & 50 & $\begin{array}{l}\text { Pdt. Dorce Dorkau } \\
\text { Debora }\end{array}$ & $\begin{array}{l}\text { Ada (Penginjilan } \\
\text { bersifat } \\
\text { Kebersamaan) }\end{array}$ \\
\hline 5 & HKBP Agave & 2004 & 250 & $\begin{array}{l}\text { Pdt. Albenar Silaen, } \\
\text { S.Th }\end{array}$ & $\begin{array}{l}\text { Ada (Person to } \\
\text { person) }\end{array}$ \\
\hline 6 & GBI Center Point & 2004 & 300 & Pdt. Ir Tjin Fen & $\begin{array}{l}\text { Ada (Person to } \\
\text { person) }\end{array}$ \\
\hline 7 & GBI Tabgha Cab. Bengkong & 2003 & 1500 & $\begin{array}{l}\text { Pdt. Filemon } \\
\text { Meliata, M.P.M }\end{array}$ & $\begin{array}{l}\text { Ada (Person to } \\
\text { person) }\end{array}$ \\
\hline 8 & $\begin{array}{l}\text { GBI Kampung Air (Batam } \\
\text { Kota) }\end{array}$ & 2009 & 40 & $\begin{array}{l}\text { Pdt. Rahmadi } \\
\text { Ginting }\end{array}$ & $\begin{array}{l}\text { Ada (Person to } \\
\text { person) }\end{array}$ \\
\hline 9 & GPT Lubuk Baja & 1995 & 13 & $\begin{array}{l}\text { Pdt. Edison } \\
\text { Sihombing }\end{array}$ & Ada (Perorangan) \\
\hline 10 & GBIS Batu Ampar & 2000 & 180 & Pdt. Yaaro Zebua & Ada (Perorangan) \\
\hline 11 & GBI Bengkong Tengah & 1992 & 75 & $\begin{array}{l}\text { Pdt. Makmur Butar- } \\
\text { Butar }\end{array}$ & Tidak Ada \\
\hline 12 & GBI Bengkong Mahkota & 2003 & 15 & $\begin{array}{l}\text { Pdt. Ferry } \\
\text { Pandiangan }\end{array}$ & Tidak Ada \\
\hline 13 & Gereja Gemindo Diaspora & 2012 & 54 & $\begin{array}{l}\text { Pdt. Pieter Up Tol } \\
\text { Seja }\end{array}$ & Tidak Ada \\
\hline 14 & $\begin{array}{ll}\text { GBI } \quad \text { Waterpoint city } \\
\text { Sekupang }\end{array}$ & 2007 & 13 & $\begin{array}{l}\text { Pdt. Sandra } \\
\text { Lodwyok }\end{array}$ & Tidak Ada \\
\hline 15 & GBI Tiban Mentarau & 2008 & 25 & $\begin{array}{l}\text { Pdt. Abdon } \\
\text { Situmorang }\end{array}$ & $\begin{array}{l}\text { Ada (Penginjilan } \\
\text { ke pulau) }\end{array}$ \\
\hline 16 & GISI Batam Kota & 1993 & 50 & $\begin{array}{l}\text { Pdt. Bungsu } \\
\text { Darmawan }\end{array}$ & $\begin{array}{l}\text { Ada (Penginjilan } \\
\text { Ke pulau) }\end{array}$ \\
\hline 17 & GPPS & 1986 & 50 & $\begin{array}{l}\text { Pdt. Hany S. } \\
\text { Gumolili }\end{array}$ & Ada (Perorangan) \\
\hline 18 & GBI House Of Glory & 2003 & \pm 1500 & $\begin{array}{l}\text { Pdt. Erwin Widjaja, } \\
\text { S.Th }\end{array}$ & $\begin{array}{l}\text { Ada (Buka } \\
\text { pelatihan misi, dan } \\
\text { gereja khusus } \\
\text { misi) }\end{array}$ \\
\hline 19 & GBKP Batam Center & 1991 & \pm 300 & $\begin{array}{l}\text { Pdt. Laharena Br. } \\
\text { Sinuhadji }\end{array}$ & $\begin{array}{l}\text { Ada (Person to } \\
\text { person) }\end{array}$ \\
\hline
\end{tabular}


Namun penginjilan pribadi lebih kepada E-0 sampai E-2, dengan kata lain penginjilan hanya dilakukan kepada jemaat setempat bahkan lingkungan orang Kristen. Mereka lebih cenderung memfokuskan penyampaian injil kepada orang-orang disekitar dulu. Orang-orang disekitar diibaratkan Yerusalem (keluarga) yang setelah itu lingkungan di sekitarnya (Yudea) dan seterusnya. Gereja lebih cenderung beranggapan bahwa penting sekali untuk dapat memenangkan keluarga bagi Tuhan. Bukan hanya keluarga, rekan-rekan atau orang-orang disekitar gereja lokal dulu. ${ }^{20}$ Bahkan Model penginjilan yang dipakai oleh gereja di kota Batam adalah model penginjilan nominal yang adalah model pendekatan yang khusus digunakan untuk mencapai orang-orang percaya yang nominal atau orang Kristen KTP. Sebagaimana yang dipaparkan oleh salah satu pendeta yang menyatakan bahwa ia memiliki konsep jemaat setempat hingga saat ini masih memerlukan bimbingan rohani untuk mengubah karakter mereka. ${ }^{21}$

Beberapa Gereja yang ada di Kota Batam mempunyai organisasi yang melakukan pelayanan misi ke daerah-daerah sebagaimana salah satu pendeta menyatakan bahwa Gereja di tempat mereka memiliki kantor sinode di Jakarta yang mana organisasi ini melaksanakan misi ke daerah-daerah dan setiap sekali setahun, organisasi ini mengundang setiap kepala gereja di masing-masing daerah untuk organisasi ini dapat melaporkan hasil pelayanan misi yang telah dilakukan. ${ }^{22}$

Dengan kata lain, Keadaan Pelayanan Misi Gereja di Kota Batam lebih banyak melakukan pelayanan misi ke dalam, dimana ini hanya membentuk karakter jemaat serta pelayanan misi dan penginjilan hanya dilakukan oleh organisasi gereja saja, belum terlihat gereja secara personal yang melakukan pelayanan misi keluar terkhusus kepada suku Melayu di Kota Batam.

\section{Hubungan Keterkaitan Tanggung Jawab Gereja dan Pelayanan Misi serta Penginjilan di Kota Batam \\ Menyadarkan Jemaat Akan Identitasnya di Dunia}

Banyak orang berpikir bahwa penginjilan harus dilakukan oleh beberapa orang di gereja, mungkin oleh pendeta atau para diaken atau oleh beberapa orang khususnya. Padahal Misi sangat berkaitan erat dengan identitas orang percaya. Identitas yang diterima oleh seseorang setelah ia percaya kepada Kristus. Bahkan di dalam identitas itu terkandung misi yang harus dijalani. Semua status dan berkat yang diterima terikat erat dengan tugas

${ }^{20}$ Bambang Sriyanto dan Roberto Ganda, "Persepsi Gembala Sidang Tentang Peran Penginjil, Gembala, Dan Guru Dalam Pelayanan Gerejawi Di GPDI Se-Kabupaten Bondowoso," Diegesis 2, no. 2 (2019): 76-90.

${ }^{21}$ Hasil Wawancara Dengan Pdt. Saharman Gea Pada Tanggal 28 Juni, 2020.

${ }^{22}$ Hasil Wawancara Dengan Pdt. Hardiantus MA Pada Tanggal 28 Juni, 2020. 
dan panggilan orang percaya sebagai gereja. Karena itu, orang Kristen yang tidak melakukan misi dalam hidupnya adalah kontradiksi dalam naturnya karena menjadi seorang Kristen berarti memanggul misi dipundaknya. ${ }^{23}$ Dengan kata lain, tidak akan ada misi jika gereja tidak mengetahui identitasnya. Dan saat orang percaya gagal untuk mengenal identitasnya sebagai gereja, biasanya misi terabaikan. Begitu juga dengan data yang telah dikumpulkan oleh peneliti, dimana gembala setempat di Kota Batam menyatakan bahwasannya jemaat dimasing-masing gereja tidak tertarik dalam melakukan misi dengan kata lain, mereka tidak mempunyai panggilan dalam melaksanakan penginjilan padahal mereka sudah mengetahui bahwasannya penginjilan itu penting. Namun mereka tidak ingin melakukannya, hal ini karena didukung beberapa faktor salah satunya yaitu mereka tidak memiliki dana dan tidak ingin meninggalkan keluarga mereka ${ }^{24}$, Dengan kata lain mereka belum mau peduli dengan keselamatan orang lain.

\section{Mengajar dan Melatih Jemaat}

Gereja perlu mengajar dan Melatih jemaat karena itu adalah suatu proses yang memuridkan orang lain agar melakukan apa yang diajarkan oleh pengajarnya ${ }^{25}$ karena hasil akhir dari pengajaran dan pelatihan yaitu untuk Menginjil dan Memuridkan orang lain lagi dan mereka bahkan siap diutus kemana saja sesuai dengan yang dikehendaki oleh pengajarnya. $^{26}$

Tidak hanya itu, Gereja bediri ditengah dunia dan berkembang terus. Selalu ada orang yang ingin menjadi anggota jemaat dan untuk mereka, pengajaran merupakan hal yang penting sekali. Sehingga gereja perlu pendidikan untuk mengajar dan melatih mereka yang sudah menjadi anggota gereja. Hal ini baik dalam mengajarkan jemaat untuk a) bersekutu dengan Tuhan, yang mana pengajaran ini menolong untuk menunjukkan jalan ke arah Allah sendiri; b) Menjadi Murid Kristus karena seorang Kristen tidak cukup hanya percaya saja kepada Kristus, tetapi bagaimana bisa menjadi murid Kristus yang sejati dan menghasilkan buah yaitu menjadi berkat bagi orang lain $^{27}$; c) Dihidupi oleh Roh Kudus dimana ketika ia mengaku percaya maka ia mempunyai roh Kudus dalam dirinya dan Roh Kudus akan menolongnya dalam segala hal. ${ }^{28}$

Mengajar dan Melatih Jemaat dalam pengaplikasiannya di gereja kota Batam telah dilakukan oleh gereja. Baik itu dalam bentuk pemberitaan Firman Tuhan disetiap ibadah minggu, ibadah komsel, ibadah lainnya. Namun lebih kepada pembentukan karakter jemaat atau kerohanian jemaat sebagaimana yang dipaparkan oleh salah satu pendeta yang

\footnotetext{
${ }^{23}$ Irfan Feriando Simanjuntak, "Surat 1 Petrus Dan Misi : Sebuah Perspektif," Real Didache 2, no. 1 (2017).

${ }^{24}$ Hasil Wawancara Dengan Pdt. Saharman Gea Pada Tanggal 28 Juni.

${ }^{25}$ Elisabeth Sitepu dan Surabina Nopriyanti Br Tarigan, "Kontribusi Pengajaran Rasul Menurut Kitab Kisah Para Rasul 2:42,47 Terhadap Minat Penginjilan Dan Kualitas Iman Jemaat GJAI Diski," Jurnal Pendidikan Religious 2, no. 1 (2020): 13-19.

${ }^{26}$ Ibid.

${ }^{27}$ Rubin Adi Abraham, Menjadi Berkat Berbuah Lebat (Yogyakarta: Andi Offset, 2011).

${ }^{28}$ Catherine Marshall, Roh Kudus Penolong Kita (Jakarta: BPK Gunung Mulia, 2000).
} 
menyatakan bahwa jemaat setempat hingga saat ini masih memerlukan bimbingan rohani untuk mengubah karakter mereka dan juga memberi pengkaderan untuk dapat menjadi seorang pemimpin ${ }^{29}$. Penyataan ini juga didukung oleh penyataan pendeta yang memiliki konsep bahwa setiap kali ia mengajarkan jemaat firman Tuhan, itu adalah misi. Bukan harus pergi keluar untuk menginji. ${ }^{30}$ Sehingga dalam hal ini, jemaat masih belum dapat menginjil dan memuridkan orang lain bahkan belum siap untuk diutus.

\section{Mengadakan Dana untuk Misi}

Gereja harus memfokuskan kepada pemberitaan injil. Namun yang terjadi di Gereja Kota Batam justru kurang memperhatikan hal itu. Hal ini didukung oleh pernyataan Junry Allow mengenai gereja sekarang kurang memfokuskan kepada pemberitaan Injil, hal ini dapat terlihat dari gereja sebagai pilar utama misi yang sangat bertanggungjawab untuk membuat Amanat Agung itu berkembang telah gagal. Gereja lebih disibukkan dengan perkembangan secara fisik saja, gereja lebih mengutamakan perkembangan dan pertumbuhan ke dalam (lebih mengutamakan pembangunan gedung gereja, gedung berAC, musik dan sound systemnya) bahkan gereja-gereja di Indonesia lebih cenderung bersaing dan mengutamakan gerejanya sendiri ataupun sinodenya sendiri. ${ }^{31}$ Padahal lebih lanjut dijelaskan oleh Eli Tanya, bahwa Gereja tidak diartikan yang sekedar berfokus kepada gedung saja, melainkan lebih kepada fungsinya yaitu sebagai mitra Allah di tengahtengah didunia. ${ }^{32}$ Begitu juga yang terjadi di gereja Kota Batam. Data yang telah dikumpulkan oleh peneliti, dimana gembala setempat di Kota Batam menyatakan bahwasannya Gereja yang ada saat ini mereka kelola lebih kebanyakan memperlengkapi kebutuhan jemaat didalam. Dan memberikan dana untuk misi hanya sebagian kecil gereja melakukannya. Hal tersebut dapat dilihat dari tabel berikut ini: ${ }^{33}$

Tabel 4. Dana Misi dalam Gereja

\begin{tabular}{|c|l|l|}
\hline NO & \multicolumn{1}{|c|}{ Nama Gereja } & Dana Misi \\
\hline 1 & GKPS Lubuk Baja & Ada \\
\hline 2 & GKIN Batam Kota & Tidak Ada \\
\hline 3 & GPDI Bethesda Batam Kota & Tidak Ada \\
\hline 4 & IFGG-Gisi Batam Kota & Ada \\
\hline 5 & GBI Waterfront City Sekupang Tiban & Tidak Ada \\
\hline 6 & 3engkong Tengah & Tidak Ada \\
\hline 7 & GKII Tiban & Tidak Ada \\
\hline 8 & GPDI Filadelphia Tiban & Tidak Ada \\
\hline
\end{tabular}

${ }^{29}$ Hasil Wawancara Dengan Pdt. Saharman Gea Pada Tanggal 28 Juni.

${ }^{30}$ Hasil Wawancara Dengan Pdt. Hardiantus MA Pada Tanggal 28 Juni.

${ }^{31}$ Junry Allow, Kepemimpinan Misi Bagi Gereja Masa Kini (Karawaci: Yayasan Damai Mulia, 2005).

${ }^{32}$ Eli Tanya, Gereja Dan Pendidikan Agama Kristen (Cianjur: STT Cipanas, 2006).

${ }^{33}$ Hasil Penelitian Kelompok Mahasiswa S2 Dalam Mata Kuliah Church Planting Dan Strategi Misi Pada Tgl 31 Oktober. 


\begin{tabular}{|c|l|l|}
\hline 9 & GBI Kampung Air Batam Kota & Ada \\
\hline 10 & GPT Lubuk Baja & Tidak Ada \\
\hline 11 & GBIS Batu Ampar & Ada \\
\hline 12 & GBI Tiban Mentarau & Tidak Ada \\
\hline 13 & GTDI Moria Batam & Ada \\
\hline 14 & GJKI Metanoia Batam & Tidak Ada \\
\hline
\end{tabular}

Gereja di kota Batam dapat di katakan belum memberdayakan jemaatnya dalam pelayanan terkhusus kepada pelayanan misi dan penginjilan terkhusus kepada suku Melayu yang adalah suku asli kota Batam dan merupakan suku yang belum terjangkau oleh pemberitaan Injil dengan kata lain, mereka belum mendengar bahwa hanya Yesus adalah satu-satunya yang dapat menebus harga kematian kekal itu. Hal ini dapat dilihat dari kendala gereja yang ditemukan didalam lapangan oleh peneliti yang telah diuraikan dalam deskripsi data penelitian. Sebagaimana hal ini sependapat dengan Tri Subekti dalam jurnalnya Pemuridan Misioner dalam Menyiapkan Perluasan Gereja Lokal yang menyatakan bahwa:

Kendala yang ditemukan sebagai tolak ukur keberhasilan pelayanan misi dan penginjilan adalah a) Fokus Jemaat pada Kegiatan dalam Ruang Gereja sehingga kegiatan yang dilakukan dalam bangunan gereja memiliki dampak atas mereka yang pergi beribadah di gereja dan hanya mengekspresikan sedikit dari apa yang Allah kehendaki yaitu menjangkau seluruh dunia-setiap orang secara pribadi; b) Pekerjaan utama yang dilupakan padahal amanat agung Yesus merupakan perintah langsung kepada murid-muridnya, itu merupakan tongkat estafet yang harus diterima oleh gereja masa kini untuk jiwa-jiwa yang terhilang dalam dunia ini c) Kesulitan dan Kurangnya Minat jemaat untuk Menginjil oleh sebab penginjilan di Indonesia sering mendapat tantangan yang besar baik melalui regulasi pemerintah setempat maupun kelompok radikal sehingga hal ini mengakibatkan spirit ketakutan akan risiko dalam menginjil.

Padahal pengembangan pelayanan melibatkan seluruh komponen gereja, termasuk jemaat, terletak pada ruang lingkup pelayanan gereja itu sendiri, serta gereja terpanggil untuk memberkati dunia dan masyarakatnya secara utuh, rohani dan jasmani. ${ }^{34} \mathrm{Hal}$ ini dapat dilihat dari hasil wawancara dengan pendeta sekota Batam dalam Lampiran.

Dengan melihat kondisi tersebut, gereja dikota Batam perlu bertanggungjawab secara luas untuk membawa masyarakatnya bergerak ke arah yang lebih baik, positif, dan berarti. Seorang Gembala, karena berbagai kesibukan tugas dan pelayanan gerejawi, seringkali mengalami keterbatasan dalam ruang lingkup pergaulannya. Waktu, tenaga, dan pikirannya diarahkan sepenuhnya kepada pelayanan-pelayanan dalam gereja sehingga hanya tersisa sedikit saja untuk ia dapat meluaskan pergaulannya dan memberikan

${ }^{34}$ Edgar D. Kamarullah, "Peran Serta Jemaat Dalam Pelayanan Holistik Gereja Menuju Transformasi Masyarakat, Suatu Upaya Pemberdayaan Jemaat Dalam Keutuhan Pelayanan Gereja,” Jurnal Teologi STT Jaffray 1, no. 1 (2003). 
sumbangsih kepada masyarakatnya. Oleh sebab itu, dengan sedikit banyak keterbatasan ruang lingkup pergaulannya seorang gembala dapat diperluas oleh jemaatnya. Dengan demikian gereja akan mengalami perluasan wilayah dan jangkauan dalam pelayanannya. Untuk itulah gereja dapat melakukan hal-hal di bawah ini:

\section{Pelayanan Misi dan Penginjilan yang Efektif}

Pelayanan misi dan Penginjilan yang efektif ke suku melayu dapat dipakai pendekatan penginjilan presensi. Penginjilan ini dilakukan dengan cara hadir di antara orang-orang yang tidak seiman untuk membangun hubungan yang baik. ${ }^{35}$ jika dilihat, Suku Melayu adalah salah satu suku yang mengidentifikasikan diri dan peradabannya dengan Islam. Hal ini dikarenakan faktor-faktor di bawah ini: ${ }^{36}$

1. Faktor perdagangan

2. Faktor perkawinan, yaitu antara pendatang Muslim dengan wanita pribumi pada tahap awal kedatangan Islam;

3. Faktor permusuhan antara orang-orang Islam dan Orang Kristen

4. Faktor politik seperti mundurnya kerajaan Hindu dan Budha seperti Majapahit dan Sriwijaya;

5. Faktor penghargaan nilai ideology Islam

6. Faktor Otoktomi, atau keadaan dimana sesuatu itu dianggap telah ada sejak purbakala sebagai kepunyaan atau sifat kebudayaan suatu masyarakat.

Sehingga gereja perlu hadir bersama mereka. Juga Seperti yang dilakukan oleh Yesus dengan melakukan model penginjilan Aktif, Ia mengambil inisiatif untuk mendekati, mencari dan memberitakan Injil kepada mereka yang belum mengenal Yesus (Yoh 4:-42), dengan membangun persahabatan yang baik, dan mengidentifikasi diri dengan mereka untuk dapat mengekspresikan kasih sayang yang penuh keperdulian dan kerelaan untuk berbagi dengan mereka. Dengan begitu, kita mendapatkan kepercayaan mereka kepada kita sehingga kita dapat mudah memberitakan Injil kepada mereka.

\section{Tugas Tanggung Jawab Gereja yang Efektif}

a. Gereja Memberikan Pengajaran dengan Konsep Pemuridan Misioner

Mengajar para warga jemaat merupakan tanggung jawab sebuah gereja. Inilah fungsi gereja yang meliputi Khotbah, sekolah minggu, kelompok-kelompok studi dan kegiatan-kegiatan pedagogis lainnya. ${ }^{37}$ Gereja bertugas untuk mengkomunikasikan dan membagkan warisan kebenaran-kebenaran Kristen kepada umatnya dan semua orang

${ }^{35}$ C. Peter Wagner, Strategi Perkembangan Gereja (Malang: Gandum Mas, 2003), 103-108.

${ }^{36}$ Muhammad Naquib Al-Attas, Islam Dalam Sejarah Dan Kebudayaan Melayu (Jakarta: Angkatan Belia Islam Malaysia, 1999), 43.

37 Tanya, Gereja Dan Pendidikan Agama Kristen, 7. 
didunia ini ia harus menafsirkan kehendak Allah kepada umatnya dan kepada dunia. Pengajaran gereja ini dapat diberikan dalam bentuk-bentuk: ${ }^{38}$

1. Ajaran Gereja (Instructon) ini merupakan pemberian informasi tentang fakta-fakta, seperti bahan-bahan ALkitab, sejarah gereja, atau doktrin (ajaran-ajaran) Kristen tidaklah cukup apabila, guru Kristen sampai disini saja dan berhenti. Gagasan ini dari kata latin "(nastru-ere)", yang artinya membangun.

2. Pendidikan gereja. Pengajaran disini melibatkan keseluruhan pribadi murid dalam proses belajar dan meliputi keterampilan, kebiasaan, sikap serta penilaian si murid yang akan dikembangkan. Ini berasal dari bahasa latin "edicare" artinya membesarkan.

3. Pembinaan gereja. Dari latin "nutrire" artinya membina dan mengasuh. Pembinaan murid pendidikan hanya lebih dasaria meliputi perkembangan, latihan dan asuhan. Dalam jemaat terhadap iklim pembinaan agama yang tujuannya adalah penyerahan diri.

Selain itu, Gereja telah ditetapkan oleh Tuhan sebagai Pengajar (guru) untuk memberikan dasar firman Allah kepada umatNya. Melaluinya membuat umat berakar kuat dan teguh dalam keyakinannya kepada Tuhan Yesus. Hal itu akan membantu menyembuhkan dan menyingkirkan kebodohan. ${ }^{39}$ Untuk itu, dalam aspek pengajaran dengan konsep pemuridan missioner ini, gereja perlu memberikan Dasar-Dasar Pemberitaan Injil yang mana orang percaya perlu miliki: ${ }^{40}$

Pertama, Dasar iman untuk melangkah yaitu tidak takut kehilangan nyawa karena Tuhan yang pelihara (Yoh.12:25-26); Kedua, Dasar Penerapan firman Tuhan untuk menjadi seorang Murid yang berkorban membayar harga, untuk menjadi seorang prajurit yang tidak memusingkan penghidupan pribadinya, untuk menjadi seorang Duta Besar atau Utusan Kristus dimana ia mewakili kepentingan kerajaan surga dan tugasnya adalah sebagai pendamai antara orang berdosa dengan penciptanya; Ketiga, dasar untuk bertahan disemua medan sehingga perlu bersemangat dan memiliki spirit of fighting; Keempat, dasar untuk pelaksanaan dimana ia perlu melangkah sebagai orang yang berhikmat secara rohani dan tajam serta peka secara rohani.

Dengan begitu, pengajaran dengan konsep pemuridan missioner itu begitu penting karena dapat memberi tujuan: ${ }^{41}$ Pertama, tujuan yang yang diorientasikan kepada usaha memenangkan jiwa baru atau petobat baru. Tujuan ini bersifat umum karena sifatnya terbuka bagi semua jemaat. Oleh karena yang menjadi sasarannya adalah mereka dapat membawa jiwa ke dalam gereja untuk bergabung menjadi jemaat. Gerejalah yang kemudian bertanggung jawab untuk membina anggota jemaat yang baru tersebut. Kedua, tujuan yang diorientasikan kepada penanaman gereja atau pembukaan jemaat lokal yang

\footnotetext{
${ }^{38}$ Ibid.
}

${ }^{39}$ Andreas Sudjono, "Pentingnya Karunia Pengajar Di Dalam Gereja," Antusias, Jurnal Teologi dan Pelayanan 3, no. 5 (2014).

${ }^{40}$ Widjaja, Misiologi, Antara Teori, Fakta Dan Pengalaman, 17.

${ }^{41}$ Tri Subekti dan Pujiwati, "Pemuridan Misioner Dalam Menyiapkan Perluasan Gereja Lokal," Epigraphe, Jurnal Teologi dan Pelayanan Kristiani 3, no. 2 (2019): 157-172. 
baru. Ini lebih bersifat ekslusif oleh karena tujuannya adalah untuk pengutusan, apakah sebagai penginjil atau penanaman gereja atau jemaat lokal. Kisah Para Rasul 9:15 menyatakan bahwa ada orang-orang pilihan untuk tugas khusus memberitakan Injil kepada bangsa-bangsa yang belum mendengar Injil.

Dengan pengajaran konsep pemuridan missioner membuat jemaat memahami akan identitasnya di muka bumi ini sebagai mitra kerajaan Allah. Untuk itulah, gereja di Kota Batam perlu mempersiapkan jemaat yang adalah mitra kerajaan Allah.

\section{b. Gereja Memberikan Pelatihan}

Memberikan pelatihan adalah salah satu cara untuk mempersiapkan jemaat untuk cakap melakukan pelayanan misi dan penginjilan. Hasil pemantauan dari simulasi. Pelayanan misi dan penginjilan ini masih banyak keterbatasan, misalnya dari pembicaraan peserta dengan yang diinjili masih sangat susah untuk menemukan titik atau jalan masuk guna menyampaikan berita Injil kepada yang diinjili. Selain itu, peserta kebingungan untuk menjawab ketika yang diinjili menanyakan soal pekerjaan, dan terkadang peserta terlalu lama memikirkan apa yang akan dibicarakan selanjutnya.

Adapun materi atau pembekalan yang harus dipersiapkan oleh gereja adalah sangat banyak didalamnya antara lain: Pembentukan karakter, latihan dalam berbagai skill atau keahlian seperti listrik, mekanik, tukang kayu, bertani, beternak, keahlian memasak, kesehatan, termasuk belajar bahasa dan lain sebagainya.

Jika dilihat apa yang dilakukan Tuhan Yesus terhadap murid-muridnya. Pelatihan kedua belas rasul adalah proses kelanjutan setelah pemilihan murid. Proses pelatihan tersebut mencakup, pertama, mendengar dan melihat menjadi saksi mata dan pelayan Firman (Luk 1;1-14). Orang banyak datang untuk mendengar Dia; karena ucapan-ucapan Yesus (Luk 6:17-49). Ucapan Yesus adalah ucapan-ucapan bahagia dan peringatan (perumpamaan) - berbahagialah mata yang melihat dan telinga yang mendengar karena banyak nabi dan orang benar yang ingin melihat, tetapi tidak melihatnya dan ingin mendengar, tapi tidak mendengarnya (Luk 6:29-49); Mat 5-7; 13:1-52). Mereka memang mempunyai telinga dan mereka mendengar. Tetapi, mereka tidak tahu apa artinya (Luk 10:23, 24; Matius 13:16-17). Dan hanya kepada murid-muridNya sajalah Yesus mengutarakan artinya (Mrk 4:33,34).

\section{c. Memfasilitasi Jemaat dalam Penginjilan}

Dalam melaksanakan pelayanan misi dan penginjilan memerlukan berbagai persiapan, baik berupa pengajaran, pelatihan, dan saatnya memfasilitasi. Gereja sebagai motor pelaksanaan bertanggungjawab untuk memfasilitasi, apapun yang diperlukan dalam teknik pelaksanaannya, sehingga jemaat termotivasi untuk lebih dalam pelaksanaannya dilapangan.

1. Persiapan Bahasa 
Dari sekian banyak yang rindu terjun dalam pelayanan, kendala yang sering dihadapi adalah kemampuan bahasa, baik itu bahasa pengantar local kemana tenaga misi tersebut diutus, demikian juga bahasa pengantar Internasional. Terkadang lemahnya kemampuan dalam berbahasa telah membuat beberapa orang menjadi ciut atau kurang bersemangat untuk terjun dalam penginjilan lintas budaya. Padahal sebenarnya masalah yang satu ini tidak perlu terjadi apabila ia sungguh-sungguh terpanggil untuk pergi, karena saat ini telah banyak tempat kursus atau lembaga bahasa yang khusus membekali setiap orang dengan bahasa asing. Sebagai solusi terhadap permasalahan bahasa ini, maka adalah sangat baik dan perlu apabila setiap calon penginjil mengambil waktu sebentar tapi serius untuk mengikuti kursus bahasa sebelum berangkat baik secara regular maupun intensif, kelompok ataupun private, setiap calon harus memperlengkapi diri.

2. Persiapan Finansial

Hal yang sangat berpengaruh dalam pelayanan misi dan penginjilan adalah perihal keuangan. Ketika seseorang diperhadapkan dengan hal ini, sangat besar kemungkinan semangat pelayanan akan surut atau bahkan ia akan mengundurkan diri karena tidak adanya uang yang menopang pelayanannya. Bagi seseorang yang mengalami persoalan dalam hal finansial, diharapkan tidak perlu panic atau bahkan surut semangatnya untuk melayani Tuhan dalam pelayanan apapun secara khusus pelaksanaan pelayanan misi dan penginjilan, karena dalam pelayanan perlu disadari bahwa pelayanan ini tidaklah melayani pekerjaan manusia. Dengan kata lain, kalau Tuhan memilih dan memanggil seseorang untuk menjadi alatNYa, maka sudah pasti Tuhan sendirilah yang akan melengkapi segala kebutuhan dalam pelayanan tersebut, sebagaimana dinyatakan dalam Matius 28:19-20 “... dan ketahuilah Aku menyertai kamu sampai kepada akhir zaman.” Untuk itu, Gereja diKota Batam perlu menguatkan dana misi utk memfasilitasi jemaat dalam penginjilan.

3. Persiapan Akademis

Akademis atau pendidikan juga perlu dipersiapkan. Persyaratan akademis ini dibuat sebenarnya bukanlah untuk mempersulit seseorang untuk bergantung dalam pelayanan terlebih dalam pelaksanaan pelayanan misi dan penginjilan. Akan tetapi bermanfaat untuk menolong dia lebih mengembangkan diri dalam bidangnya. Pengetahuan dan wawasan yang luas juga merupakan modal utama dalam melayani Tuhan secara holistik. "Setiap orang yang sudah mengalami keselamatan dari Allah seharusnya menceritakan bagian yang sudah dia ketahui kepada orang lain. Memberitakan Injil dan melengkapi diri harus berjalan seiring, sama seperti mengajar harus diimbangi dengan belajar, supaya baik pengetahuan diri maupun mutu pengajaran semakin meningkat." 42

\section{Motivasi Pribadi}

Tidak sedikit jemaat dalam pelaksanaan penginjilan yang kurang jelas, atau memiliki motivasi yang salah dalam menentukan pilihannya sebagai calon penginjil. Diantara mereka ada yang mengira bahwa dengan menjadi seorang penginjil persoalan

\footnotetext{
${ }^{42}$ Steven Tong, Teologi Penginjilan (Surabaya: Momentum, 2000), 6.
} 
mereka akan selesai. Ada juga yang berharap bahwa menjadi seorang tenaga misi akan mendapatkan gaji yang besar. Dan yang lainnya berfikir bahwa menjadi seorang calon missionaris semuanya serba gampang sehingga tidak perlu mempersiapkan diri lebih baik. Motivasi-motifasi seperti di atas adalah merupakan motivasi yang salah. Ini perlu diluruskan kembali dan setiap orang yang mempunyai kerinduan melayani di lading penginjilan sebaiknya menguj kembali motivasinya, dengan bertanya dalam hati, "Apakah saya sudah siap menjadi seorang penginjil, apakah saya benar-benar terpanggil untuk melayani? Negara atau daerah mana yang Tuhan taruh di hati saya? Pertanyaan-pertayaan ini sangat perlu mendapat suatu jawaban yang pasti dari Tuhan supaya nantinya tidak sampai kecewa karena tidak sesuai dengan harapan-harapan sebelumnya. Hal ini lebih ditegaskan lagi oleh Robert E Coleman bahwa: "Dalam melayani Tuhan, kasih yang sempurna merupakan ukuran paling utama satu-satunya (Mat 5:48) dan kasih itu harus tampak dalam ketaatan kepada Kristus (Yoh 14:21, 23)serta tampak dalam pelayanan kepada sekalian bangsa karena untuk keselamatan merekalah. Kristus sudah mati (Mat 25:31-36). Di dalam kasih itu terletak salib, yaitu penyangkalan diri dengan rela demi kepentingan orang lain (Mat 16:24-26; 20:17-28; Mrk 8:34-38; Yoh 12:25; 13:1-20) ${ }^{43}$

\section{d. Mengutus Para Penginjil}

Dalam melakukan tugas pelaksanaan pelayanan misi dan penginjilan gereja perlu mengadakan pengutusan pelaksanaan penginjilan. Dalam pengutusan ini ada dua macam pengutusan.

Pertama, pengutusan perorangan atau seorang diri.Hal ini apa yang pernah Yesus lakukan seorang diri, menemui dan menyampaikan berita keselamatan itu (Yoh 4; Luk 19:1-10). Kedua pengutusan dalam bentuk kelompok. Dalam Injil Lukas, Yesus mengutus 70 murid. 70 murid yang diutus secara berdua-dua untuk bersaksi bagi TUhan (Luk 10:1). Tidak dijelaskan siapa murid -murid yang lain ini, tetapi ada tanda-tanda yang menyatakan bahwa di antara mereka juga termasuk kedua belas murid yang pertama. Jumlah rombongan ini juga menunjukkan hasil dari pekerjaan kedua belas murid dalam bersaksi bagi Kristus.

Tugas-tugas rombongan yang lebih besar ini banyak yang serupa dengan apa yang sebelumnya sudah diberikan kepada kedua belas murid (Luk. 10:2-16). Hanya saja, ada suatu tambahan dalam menjalankan tugas baru ini, yaitu agar mereka pergi mendahului Yesus "ke setiap kota dan tempat, yang hendak dikunjungiNya (Luk 10:1). Dengan kata lain, jemaat-jemaat menjadi utusan-utusan gereja bagi Tuhan untuk mempersiapkan segala sesuatu bagi pelayananNya. Dengan memberi semacam orientasi yang lebih jelas seraya memberi mereka suatu harapan bahwa Tuhan pasti menolong dalam setiap persiapanpersiapan untuk berangkat. Suatu sikap yang terbaik adalah mencoba memposisikan mereka dengan diri sendiri, serta mengingat bahwa kebanyakan calon missionaris adalah

\footnotetext{
${ }^{43}$ Robert E. Coleman, Rencana Agung Penginjilan (Bandung: Yayasan Kalam Hidup, 1964), 3.
} 
buta (tidak tahu banyak) dalam hal pelayanan misi lintas budaya jadi perlu diberikan suatu pengertian dengan bijaksana bukan dengan menggurui tetapi memberi dorongan kepada calon missionaris.

Jadi sebenarnya tugas itu bukanlah sesuatu yang tidak mereka ketahui sebelumnya. Hal ini semata-mata hendak menunjukkan kembali bahwa mereka semua harus mempraktikkan strategi pelayanan misi dan penginjilan yang telah mereka pelajari dari Tuhannya.

\section{KESIMPULAN}

Gereja didunia ini, terkhusus bagi Gereja di Kota Batam adalah pelaksana dari misi Allah baik sebagai organisasi dan organisme bertanggungjawab penuh pada pelaksanaan tugas yang diberikan. Bahkan Gereja terkhusus di Kota Batam bertanggungjawab penuh sebagai pemegang kunci Kerajaan Sorga, yaitu tempat yang Allah inginkan semua orang masuk di dalamnya, sehingga gereja di Kota Batam perlu melakukan transformasi kehidupan manusia pribadi maupun masyarakat setempat yang merupakan suku asli kota Batam yang adalah suku Melayu. Dengan melakukan tugas tanggungjawabnya yang adalah memberdayakan jemaatnya dalam pelayanan misi dan penginjilan, baik lewat pengajaran dengan konsep pemuridan missioner, pelatihan untuk cakap melakukan pelayanan misi dan penginjilan, memfasilitasi jemaat dalam pelayanan misi dan penginjilan, hingga jemaat dapat diutus untuk menuntaskan Amanat Agung. sehingga tugas tanggungjawab gereja bukan hanya menjadi tugas gembala gereja namun juga merupakan tugas dari semua komponan gereja. Untuk itu, gereja di Kota Batam dalam melaksanakan tugas tanggungjawab dapat memberdayakan jemaatnya untuk dapat memahami akan identitasnya sebagai mitra Allah di dunia ini untuk memberitakan kabar keselamatan yang datangnya hanya dari Yesus yang adalah penebus harga kematian kekal itu

Untuk dapat menuntaskan tugas amanat Agung yang adalah perintah Yesus, dibutuhkan gereja baik secara organisasi dan organisme yang dapat memahami tugas tanggungjawabnya sebagai mitra kerajaan Allah di muka bumi ini. Bukan hadir di dunia ini dan tidak memberikan dampak apa-apa atau bahkan tidak peduli akan keselamatan orang lain. tetapi baiklah gereja terkhusus kepada gereja di Kota Batam ada untuk membawa suatu perubahan.

\section{KEPUSTAKAAN}

Abraham, Rubin Adi. Menjadi Berkat Berbuah Lebat. Yogyakarta: Andi Offset, 2011. Al-Attas, Muhammad Naquib. Islam Dalam Sejarah Dan Kebudayaan Melayu. Jakarta: Angkatan Belia Islam Malaysia, 1999.

Allow, Junry. Kepemimpinan Misi Bagi Gereja Masa Kini. Karawaci: Yayasan Damai Mulia, 2005.

Berkhof, Louis. Teologi Sistematika, Volume 5. Surabaya: Lembaga Reformed Injili Indonesia, 1997. 
Coleman, Robert E. Rencana Agung Penginjilan. Bandung: Yayasan Kalam Hidup, 1964. Downey, Murray W. Cara-Cara Memenangkan Jiwa. Bandung: Yayasan Kalam Hidup, 1957.

Ellis, D. W. Metode Penginjilan: Istimewa Tepat Guna Bagi Penginjil Awam Praktis Dan Taktis. Jakarta: Yayasan Komunikasi Bina Kasih OMF, 1999.

Ganda, Bambang Sriyanto dan Roberto. "Persepsi Gembala Sidang Tentang Peran Penginjil, Gembala, Dan Guru Dalam Pelayanan Gerejawi Di GPDI Se-Kabupaten Bondowoso." Diegesis 2, no. 2 (2019): 76-90.

GP, Harianto. Pengantar Misiologi, Misiologi Sebagai Jalan Menuju Pertumbuhan. Yogyakarta: Andi Offset, 2012.

Hutagalung, Fransiskus Irwan Widjaja, Daniel Ginting, Sabar Manahan. Mengutip Centre for the Study of Global Christianity, Christianity in Global Context, 1970.

Kamarullah, Edgar D. "Peran Serta Jemaat Dalam Pelayanan Holistik Gereja Menuju Transformasi Masyarakat, Suatu Upaya Pemberdayaan Jemaat Dalam Keutuhan Pelayanan Gereja.” Jurnal Teologi STT Jaffray 1, no. 1 (2003).

Kuiper, Arie De. Missiologia: Ilmu Pekabaran Injil. Jakarta: BPK Gunung Mulia, 2006.

Marshall, Catherine. Roh Kudus Penolong Kita. Jakarta: BPK Gunung Mulia, 2000.

Packer, J. I. Penginjilan Dan Kedaulatan Allah Evangelism And The Sovereignty of God. Surabaya: Momentum, 2003.

Pujiwati, Tri Subekti dan. "Pemuridan Misioner Dalam Menyiapkan Perluasan Gereja Lokal.” Epigraphe, Jurnal Teologi dan Pelayanan Kristiani 3, no. 2 (2019): 157-172.

Ryrie, Charles C. Teologi Dasar, Buku 2. Yogyakarta: Andi Offset, 2000.

Simanjuntak, Irfan Feriando. "Surat 1 Petrus Dan Misi : Sebuah Perspektif." Real Didache 2, no. 1 (2017).

Sudjono, Andreas. "Pentingnya Karunia Pengajar Di Dalam Gereja." Antusias, Jurnal Teologi dan Pelayanan 3, no. 5 (2014).

Tanya, Eli. Gereja Dan Pendidikan Agama Kristen. Cianjur: STT Cipanas, 2006.

Tarigan, Elisabeth Sitepu dan Surabina Nopriyanti Br. "Kontribusi Pengajaran Rasul Menurut Kitab Kisah Para Rasul 2:42,47 Terhadap Minat Penginjilan Dan Kualitas Iman Jemaat GJAI Diski.” Jurnal Pendidikan Religious 2, no. 1 (2020): 13-19.

Thiessen, Henry Clarence. Teologi Sistematika. Malang: Gandum Mas, 2003.

Tomatala, Yakob. Teologi Misi. Jakarta: YT Leadership Foundation, 2003.

Tong, Steven. Teologi Penginjilan. Surabaya: Momentum, 2000.

Wagner, C. Peter. Strategi Perkembangan Gereja. Malang: Gandum Mas, 2003.

Widjaja, Fransiskus Irwan. Misiologi Antara Teori, Fakta Dan Pengalaman. 1st ed.

Batam: Andi Offset Yogyakarta, 2018.

- Tentang Data Gereja, 2015.

"Badan Pusat Statistik Kota Batam," n.d.

Hasil Penelitian Kelompok Mahasiswa S2 Dalam Mata Kuliah Church Planting Dan Strategi Misi Pada Tgl 31 Oktober, 2019.

Hasil Wawancara Dengan Pdt. Hardiantus MA Pada Tanggal 28 Juni, 2020.

Hasil Wawancara Dengan Pdt. Saharman Gea Pada Tanggal 28 Juni, 2020.

Hasil Wawancara Dengan Pdt. Tulus Sihombing Pada Tgl 31 Oktober, 2019.

"Https://Www.Google.Com/Maps/Search/Gereja+yang+ada+di+kota+batam/@0.8685112, 104.0001183,10.5z?Hl=id." 12 Juni 2020. 